Bulgarian Academy of Sciences. Space Research and Technology Institute.

Aerospace Research in Bulgaria. 32, 2020, Sofia

DOI: https://doi.org/10.3897/arb.v32.e15

\title{
INFLUENCE OF LONG-TERM STAY OF ELEMENTS OF CAPILLARY INTAKE DEVICES IN LIQUID PROPELLANT COMPONENTS ON THEIR PARAMETERS
}

\author{
Oleksandr Minai, Oleg Ivanov, Ihor Siedykh \\ Design Office "YUZHNOYE”, Dnepr, Ukraine \\ e-mail: info@yuzhnoye.com
} \begin{abstract}
Corrosion Rate
\end{abstract}
Keywords: Capillary Intake Devices; Mesh Phase Separators; Capillary Holding Capacity,

\begin{abstract}
In this paper, we consider the results of a long-term study of the effect of prolonged stay (more than 30 years) of elements of capillary intake devices - mesh phase separators in the liquid propellant components (and under vapors) on the change in their working parameters (characteristics). In the process of research, the following types of work were carried out: extracting mesh phase separators from the propellant tanks of the missile stages to be detected after they were neutralized; analyzing the chemical composition of the substances located on the grids of mesh phase separators; determining the capillary holding capacity of the mesh, measuring the geometric dimensions of the mesh by the optical method; and performing metallographic studies of the mesh patterns.

As a result, the authors determined the decrease in the capillary holding capacity of the screen of mesh phase separators for 31 years of their stay in the liquid propellant components and under their vapor. The analysis of the main factors was made that influenced the change in the design parameters of the capillary intake device: uniform corrosion damage and local changes in the microstructure of the structural material of the meshes, as well as a change in the value of the contact angle of the propellant with the mesh material.
\end{abstract}

\section{Introduction}

Progress in space exploration is largely going along the path of creating and launching new spacecraft, as well as expanding the existing (International Space Station) and creating (in the future) a new space infrastructure for their maintenance and operation. The increase in the scale of space activity and its ever-increasing commercial orientation put forward special requirements for spacecraft, which determine the development process in this area. This is the possibility of reusable use and long-term operation of spacecraft [1].

The development of reusable spacecraft landing on Earth or transporting goods in space with a launch from low Earth orbit presents new requirements for all nodes and units, including mesh (capillary) phase separators, as the main functional 
elements of capillary intake devices included in the system for ensuring the continuity of the supply of propellant components at the entrance to liquid rocket propulsion systems $[2,3]$.

At the same time, the following questions are becoming urgent: studies of near and far space, the study and development of planets and bodies of the solar system (moon, Mars, the sun, planetary satellites, asteroids, etc.). This will require the creation of [4-7]:

- research and observation satellites;

- space tugs of reusable use;

- space shuttles for the delivery of people and goods with the ability to land on the planet and return to the orbital station;

- long-running infrastructure facilities: space and orbital stations of various kinds, equipped with docking facilities, tugboats, tankers, propellant depots and personnel modules.

The creation, operation and maintenance of the above objects entails the need for permanent storage at orbital stations of various technical fluids transported from the Earth, including high-boiling liquid propellant components: an oxidizing agent - dinitrogen tetroxide $\mathrm{N}_{2} \mathrm{O}_{4}$ (AT) and combustible - unsymmetrical dimethylhydrazine $\left(\mathrm{CH}_{3}\right)_{2} \mathrm{~N}_{2} \mathrm{H}_{2}$ (UDMH), followed by filling them with orbit spacecraft. At present, these propellant components are widely used in rocket technology, in particular, in Proton, Cyclone, Titan, Arian rocket launchers, liquid ICBMs, in propulsion systems of manned ships, satellites, orbital and interplanetary space stations.

Obviously, their refueling and operation will occur under microgravity conditions. Therefore, it is advisable that the propellant tanks of space stations and spacecraft be equipped with capillary intake devices. Capillary intake devices and their elements will have to be able to work with large numbers of "filling-emptying" cycles (100 or more) and with a long active period of work in space (more than 15 years) [1].

Thus, at the present stage of development of space programs, the following requirements will be imposed on storage systems and liquid withdrawal in general and on capillary intake devices, as their integral part [1]:

- the possibility of reusable use;

- long period of operation;

- performance in aggressive environments.

At the same time, the operation of functional elements of systems (including mesh phase separators of capillary intake devices), when all of the above requirements are implemented, should take place without significantly reducing their operating parameters (characteristics) throughout the entire period of operation [1].

In this article, the authors present the results of many years of research on the effect of long-term storage (more than 30 years) of net phase separators in 
components and under pairs of liquid propellant components (AT and UDMH) on the change in their operating parameters (characteristics).

\section{Object of research and parameters studied}

In this work, the object of research was the main functional element of the capillary intake device, which ensures the multiple launch of the propulsion system of the spacecraft under zero gravity conditions and the reduction of undeveloped residues of propellant components, the principle of which is based on the capillary forces of the surface interaction - mesh phase separator [8-10].

The mesh phase separator under study was made of steel mesh No. 008 (steel grade AISI 321), which is a twill weave fabric with square cells, having the following characteristics according to the technical specifications [11]:

- wire diameter $55_{-3}^{+4}$ microns;

- nominal cell size in the light of 80 microns;

- permissible deviations of the arithmetic mean cell size $\pm 13 \%$;

- permissible deviation of the size of an individual cell $+75 \%$;

- allowable deviation of the size of especially large cells 50-70\%;

- the permissible number of especially large cells is not more than $9 \%$, on a grid with an area of $1 \mathrm{~m}^{2}$.

A schematic representation of a twill weave of wire cloth with square cells is shown in Fig. 1.

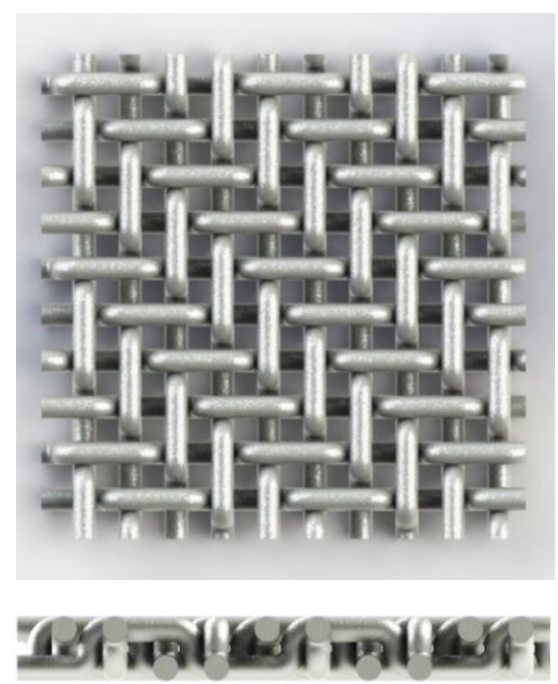

Fig. 1. Schematic representation of a twill weave of wire mesh with square cells 
Since the principle of operation of the mesh phase separator is based on capillary forces acting in the grid cells at the gas-liquid phase boundary, the main parameter of its operability is capillary holding capacity.

Capillary holding capacity is the ability to prevent the penetration of free vapor-gas inclusions through a mesh phase separator under external power influences on propellant components. This parameter depends on the cell size, surface purity and wire material, type and temperature of the propellant components $[1,12-13]$.

The value of the Capillary holding capacity of the mesh phase separator is determined by the formula [12-15]:

$$
\Delta H=\frac{k \cdot \sigma}{\rho \cdot g \cdot b} \cdot \cos \theta
$$

where $\mathrm{k}$ is a coefficient that take into account the geometry of the mesh cell; $\sigma$ is the coefficient of surface tension of the propellant components; $\rho$ is the density of the propellant components; $g$ is the longitechnical specificationdinal acceleration; $\mathrm{b}$ is the mesh cell size; $\theta$ is the contact angle between the propellant and the grid material, which is assumed to be equal to zero under nominal conditions for the propellant under consideration.

In spacecraft that have been in a charged state for a long time (15 years or more) under the influence of aggressive propellant components (AT and UDMH), the operational parameters of the mesh phase separators of capillary sampling devices can change.

The reasons for the change in the design parameters of the mesh phase separators of capillary sampling devices include the formation of films, gels, precipitation grids on the surface of the wire as a result of corrosion processes, with prolonged exposure to aggressive propellant (AT and UDMH) on the construction materials of meshes, which, in addition to measuring the change in the geometric dimensions of the wire and mesh cells can affect the value of the contact angle and lead to a decrease in the capillary holding capacity.

Since there was no experimental determination of the change in the contact angle, it was not possible to theoretically evaluate the influence of this factor on the capillary properties of fine-meshed meshes.

Based on the foregoing, in order to determine the effect of a long stay of elements of capillary intake devices in the components of liquid propellant components on their parameters, we studied the changes in the capillary holding capacity of the mesh phase separators of the screen meshes of the propellant components that were in the liquid phase (AT and UDMH) and under them in vapors for a) 15 years, b) 17 years and 6 months, c) 20 years, d) 20 years and 10 months, e) 23 years and f) 31 years, being in the propellant systems of refueling and ampouled space stages of rocket.

The work was carried out in stages in the period from 1997 to 2016. 
According to the adopted test program, the work was performed in the following order:

1) removing the mesh phase separator from the propellant tanks of the vehicles being and analysing the chemical composition of substances located on the screen of the mesh phase separator;

3) determining the capillary holding capacity of the mesh phase separator;

4) measuring the geometric dimensions of the screen of the mesh phase separator with an optical method;

5) doing metallographic studies of screen mesh patterns of the phase separator.

Moreover, in addition to the detectable mesh phase separators, the work in items 3) and 4) was first carried out on new meshes No. 008 in order to obtain reference data for the existing test conditions, experimental designs, and working fluids.

\subsection{Analysis of the chemical composition of substances located on the screen of mesh phase separators after its removing from the propellant tanks}

After neutralization, the propellant tanks were opened and the mesh phase separator was dismantled.

Three samples of mesh No. 008, located in different parts of the tank, both in the liquid phase of the propellant components and under its vapor, were extracted from each propellant tank.

The following methods were used to determine the composition of substances found on the networks of phase-separated meshes: X-ray fluorescence, $\mathrm{X}$-ray structural, atomic absorption, potentiometric, IR Fourier spectroscopy and chromatography-mass spectrometry.

Thus, the studies showed that the composition of cations on mesh of oxidizer and fuel tanks is almost the same. The detected metal cations correspond to the elements that make up the alloy of aluminum and steel - the main structural materials of the defective fuel system. However, due to the small amount of the substance on the mesh in contact with UDMH, it was not possible to establish its composition by the methods listed above.

\subsection{Determination of capillary holding capacity of mesh phase separators}

Tests of the mesh phase separator were carried out in a pilot plant. The experimental device is shown in Fig. 2. 


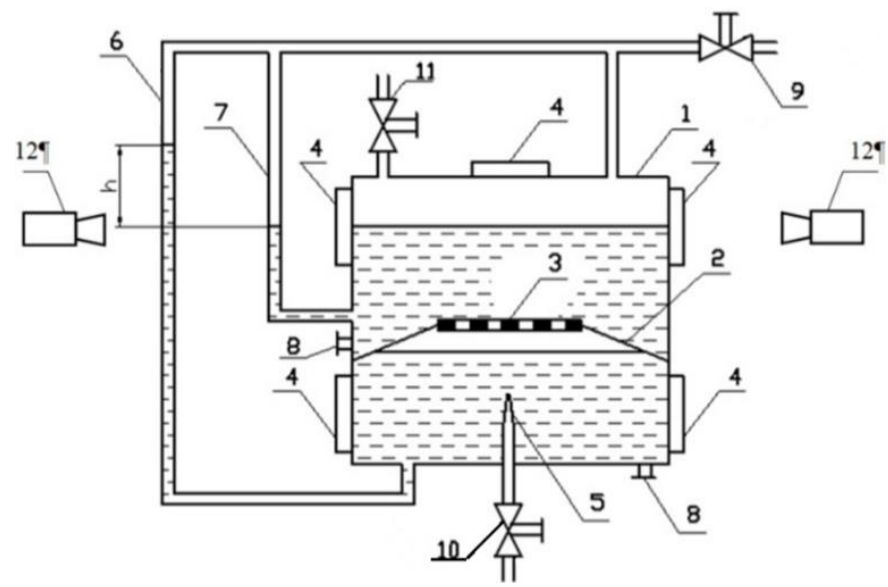

Fig. 2. Scheme of the experimental device for determining the capillary holding capacity of the mesh phase separators

In Fig. 2 is shown: 1 - cylindrical container; 2 - a partition; 3 - CPS; 4 - porthole; 5 - fitting with a calibrated nozzle; 6,7 - piezometers; 8 - filling and drain fitting; 9 - valve for the removal of vapor of the working fluid; 10 - valve dosed gas supply; 11 - valve boost the upper compartment; 12 - video cameras.

In Fig. 3, as an example, photographs of a single breakthrough of gas bubbles and a mass breakthrough in whole groups of cells are presented.

To obtain the reference data, control samples of mesh phase separators using standard technology from the same mesh roll were prepared. Tests of the reference mesh phase separators were carried out according to the same procedure.

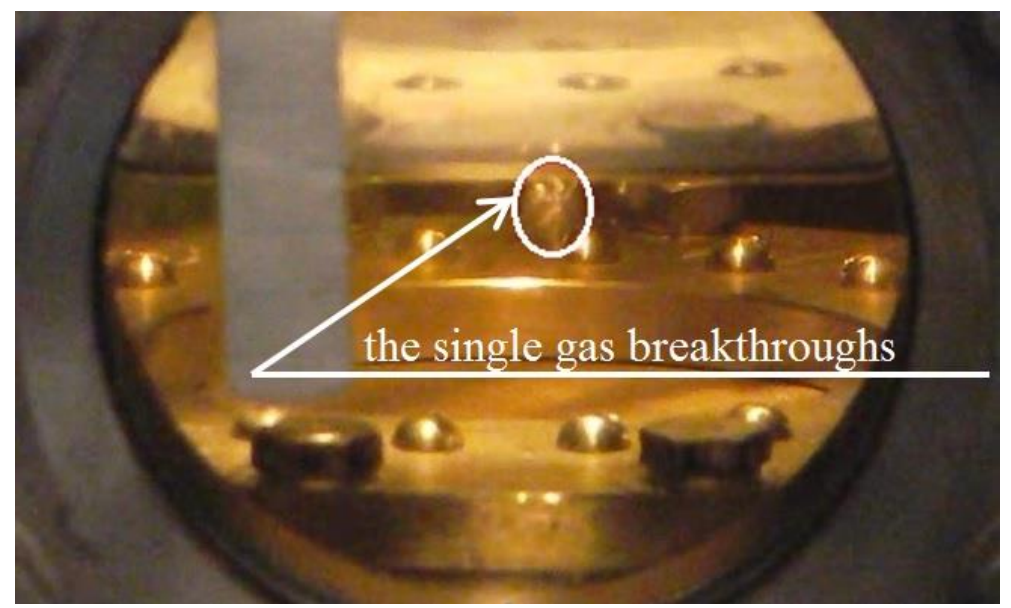

A 


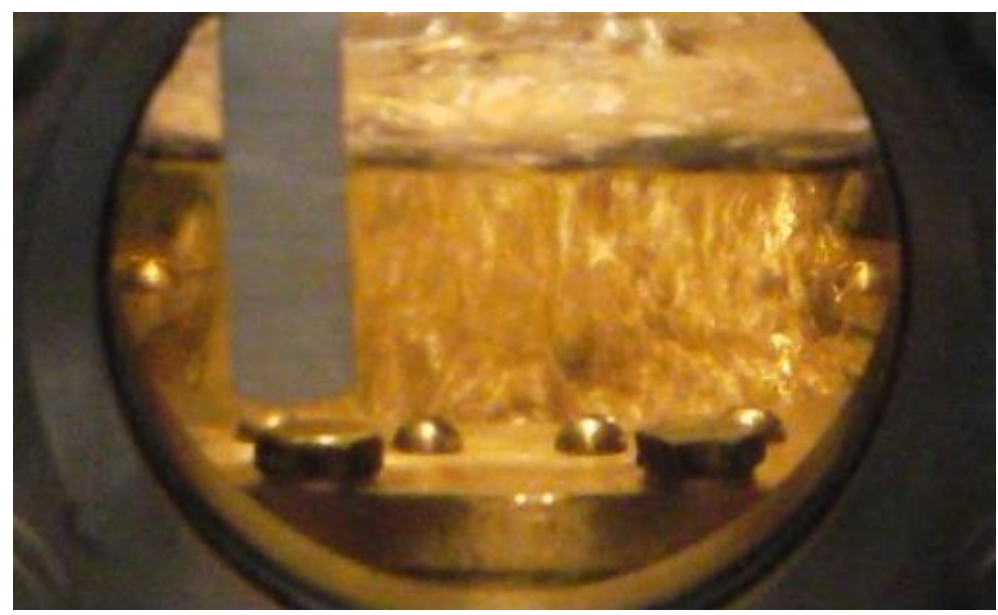

B

Fig. 3. Photographs of the single breakthrough of gas bubbles (A) and the mass breakthrough over whole groups of cells $(B)$

More than 56 samples of meshes (including reference ones) that were in the liquid phase of the propellant components and under their vapor for a period of a) 15 years, b) 17 years and 6 months, c) 20 years, g were tested. d) 20 years and 10 months, e) 23 years and f) 31 years, as part of the propellant systems of refueling and amplified space rocket stages.

AT and UDMH were used as working fluids, which are identical to those normally supplied to rocket propellant systems.

The tests were carried out in the temperatures range:

- plus 1 - plus $18^{\circ} \mathrm{C}$ - for AT;

- plus 1 - plus $16^{\circ} \mathrm{C}$ - for UDMH.

In total, it was carried out:

- 364 tests to determine the capillary holding capacity of mesh phase separators at AT;

- 337 tests to determine the capillary holding capacity of mesh phase separators at UDMH.

The array of experimental data obtained as a result of the tests was approximated by linear dependence by the least squares method.

Fig. 4 summarizes the test results to determine the capillary holding capacity of the mesh phase separators, mesh samples after 15-31 years of their presence in the highly toxic and aggressive components of liquid rocket propellant and under their vapors - AT (A) and UDMH (B) depending on temperature. 


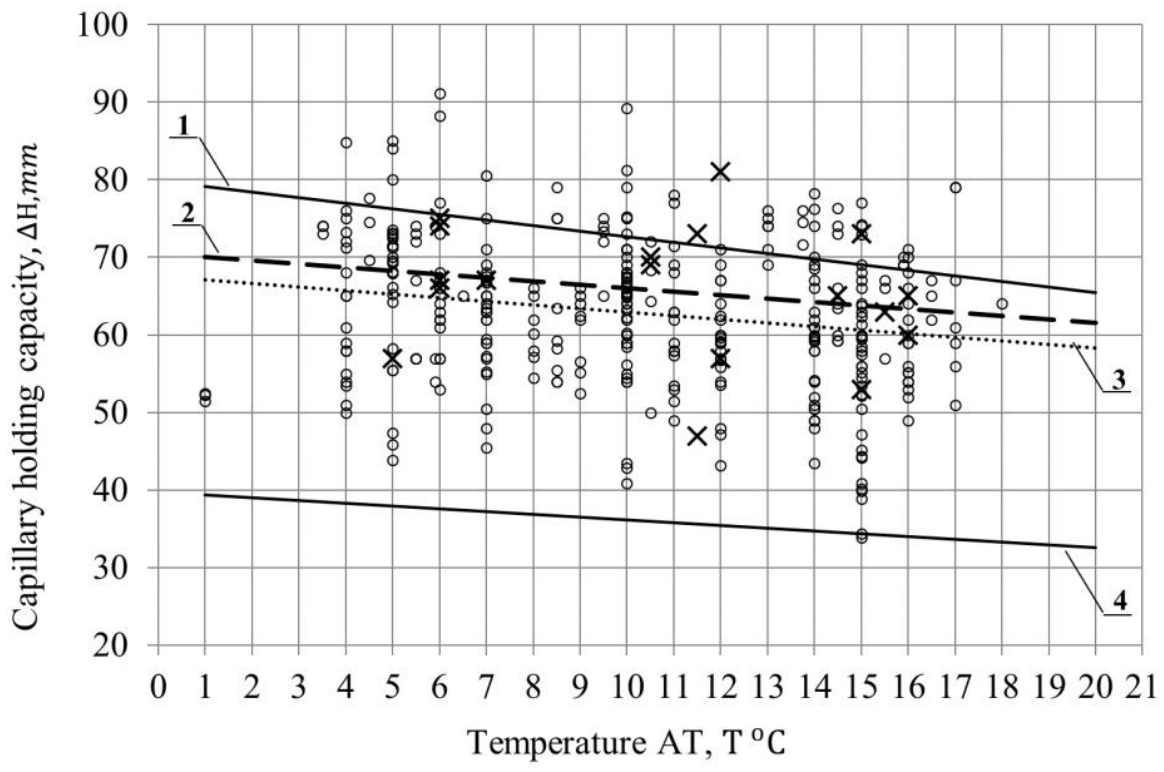

A

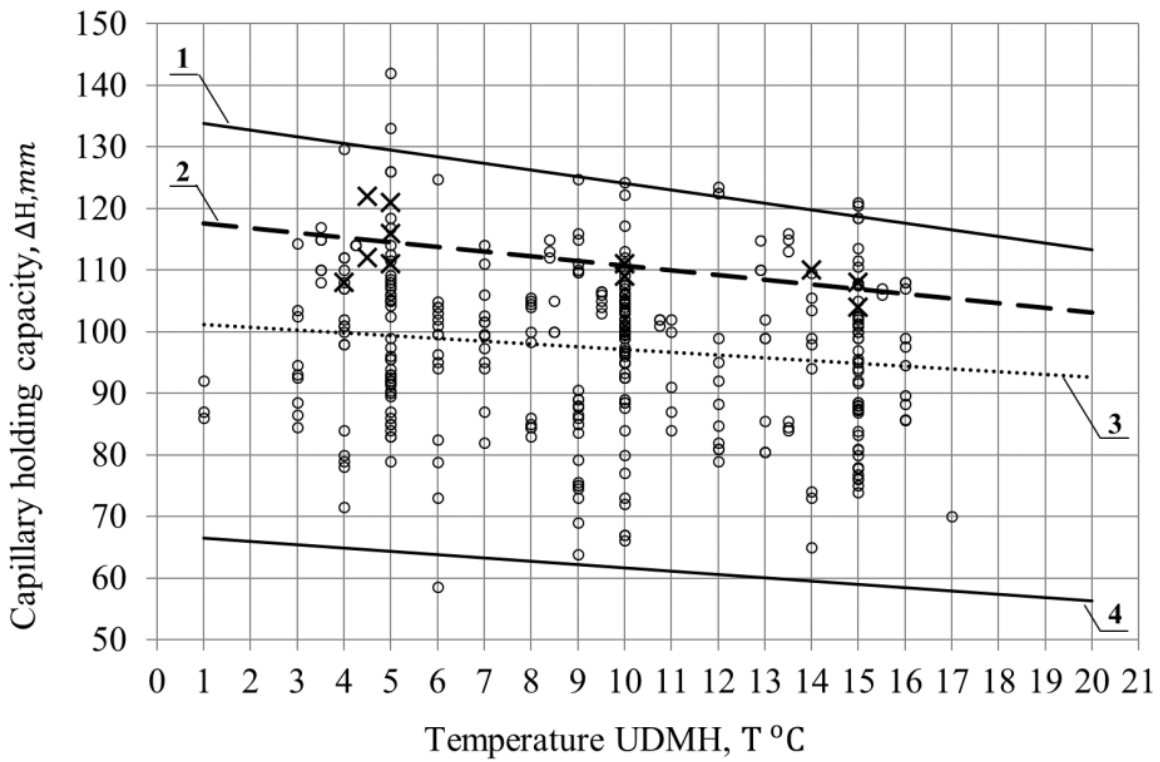

B

Fig. 4. Dependence of the capillary holding capacity of the samples of the mesh phase separator at temperature: $A$ - for AT; $B$ - for UDMH

In Fig. 4 shows: 1 - the upper limit of capillary holding capacity, calculated in accordance with the data on the permissible deviations of the geometric 
parameters of the mesh No. 008; 2 - approximation of the test results to determine the capillary holding capacity of the reference mesh patterns; 3 - approximation of the test results to determine the capillary holding capacity of the mesh phase separator after a long stay in the fuel components; 4 - the lower boundary of the capillary holding capacity, calculated in accordance with the data on the permissible deviations of the geometric parameters of mesh No. $008 ; \times-$ the values of the experimental determination of the capillary holding capacity of the reference mesh samples; $\mathrm{o}-$ the values of the experimental determination of the capillary holding capacity of the mesh phase separator after a long stay in the propellant components.

\subsection{Optical method for measuring the geometric dimensions of mesh phase separators}

To draw conclusions about the presence and magnitude of corrosion of the wires of the mesh phase separator, their initial geometric parameters (dimensions) must be known. For this, the dismantled mesh phase separators and reference mesh samples No. 008 were investigated by the optical method.

Measurements were made uniformly over the screen area in several zones not lying along the same wires. In each zone, in two perpendicular directions, "wirecell-wire ..." measurements were performed in succession, 10 pieces of each element.

The main geometric parameters of the dismantled mesh phase separators and reference mesh samples are shown in Fig. 5.

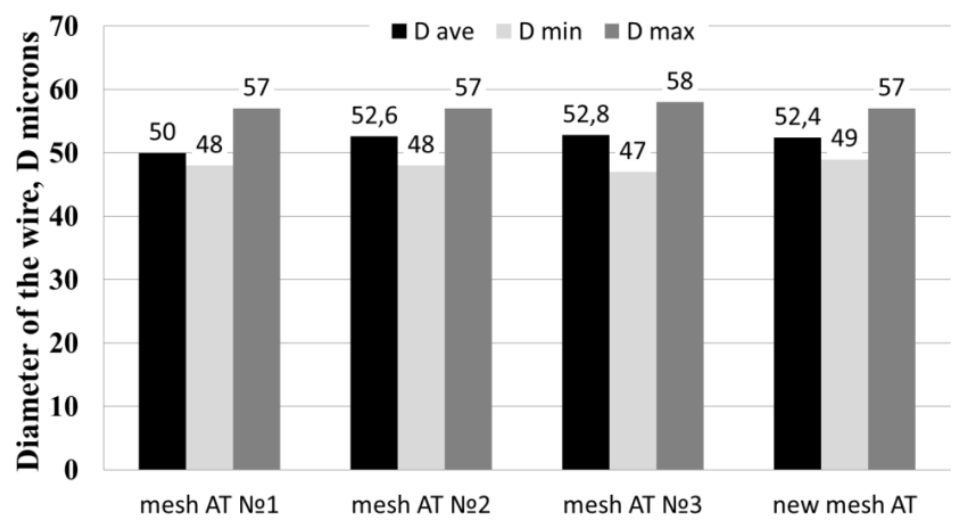

A 


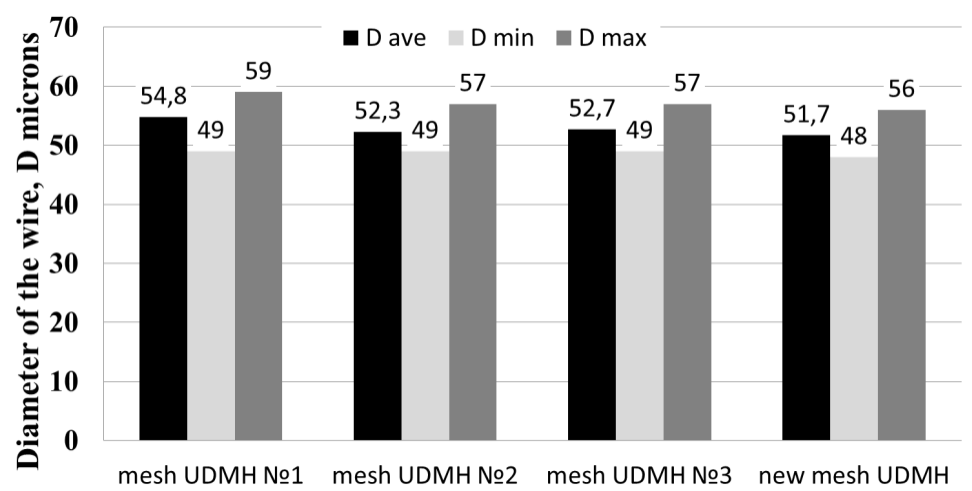

B

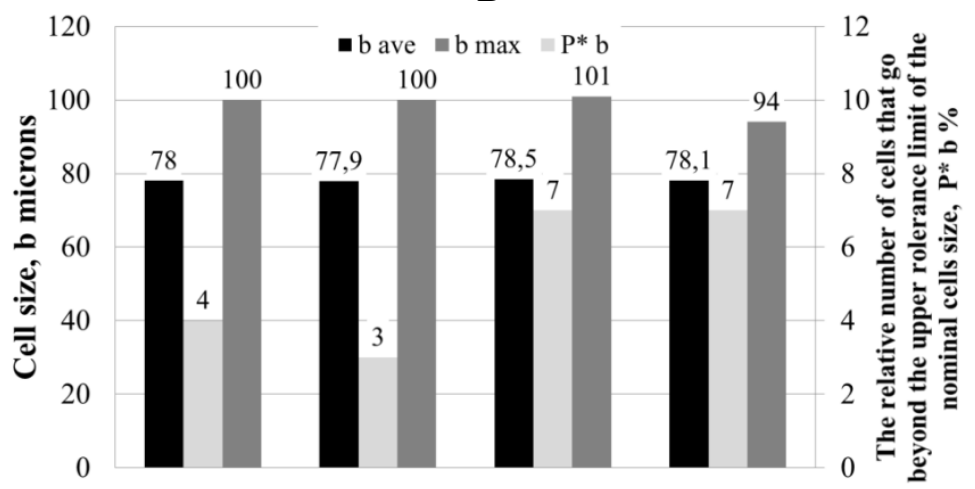

mesh AT №1 mesh AT №2 mesh AT №3 new mesh AT

C

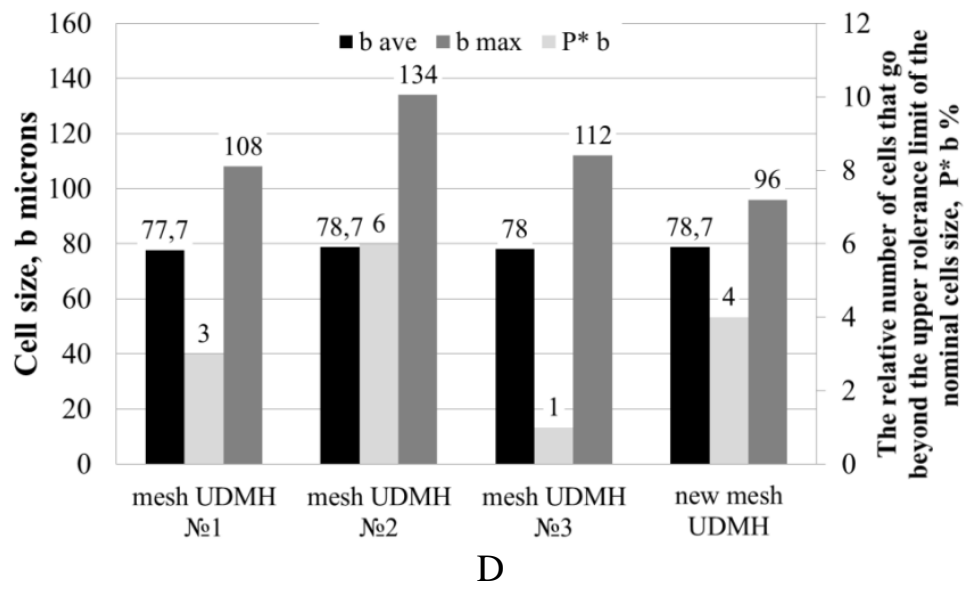

Fig. 5. The main geometric parameters of the dismantled mesh phase separators and reference mesh patterns: A - the basic geometric parameters of the wire mesh AT; $B$ - the basic geometric parameters of the wire mesh UDMH; $C$ - the basic geometric parameters of the cells of the grids of the AT; $D$ - the basic geometric parameters of the mesh cells $U D M H$ 
In Fig. 5 shows: D ave. - the arithmetic mean of the diameter of the wire; D min - the smallest value of the diameter of the wire; D max - the largest value of the diameter of the wire; $b$ ave. - the arithmetic mean value of the cell size; $b$ max maximum cell size; $\mathrm{P} * \mathrm{~b}-$ the relative number of cells that go beyond the upper tolerance limit of the nominal cell size.

From the graphs shown in Fig. 5 (C, D), it can be seen that the cell sizes of all mesh phase separators correspond to technical specification.

\subsection{Metallographic studies of mesh phase separator}

The purpose of the metallographic study was to determine the state of the screen of the mesh phase separators after prolonged exposure to propellant components.

For a metallographic study, samples (fragments) were cut out of the working part of the screen of mesh phase separators for the preparation of microsections, the studies of which were carried out using a metallographic optical microscope, which allows direct visual observation and photographing with an increase of 50 to 1000 times. The study revealed the presence of corrosion lesions and changes in the microstructure of materials in the samples.

Fig. 6 presents, as an example, the photographs of non-etched macro sections and the micro-structure of steel, indicating the absence of corrosion damage and changes in the microstructure of the structural materials of the mesh after a long stay in the propellant components - AT and UDMH.

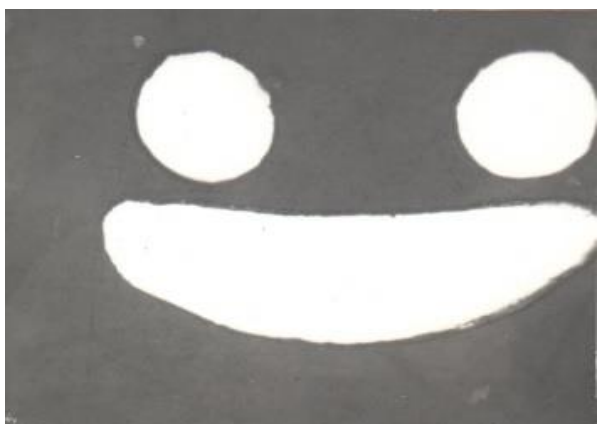

A

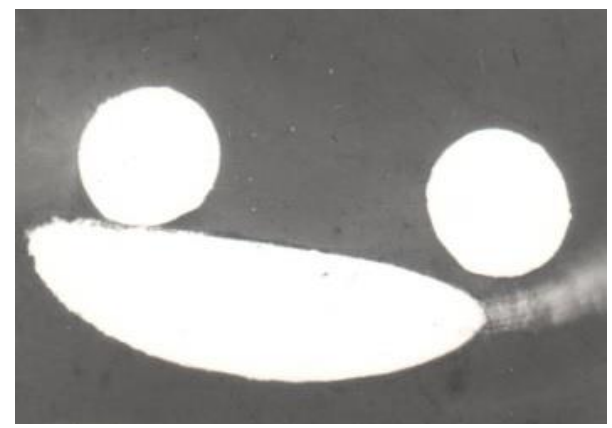

B 


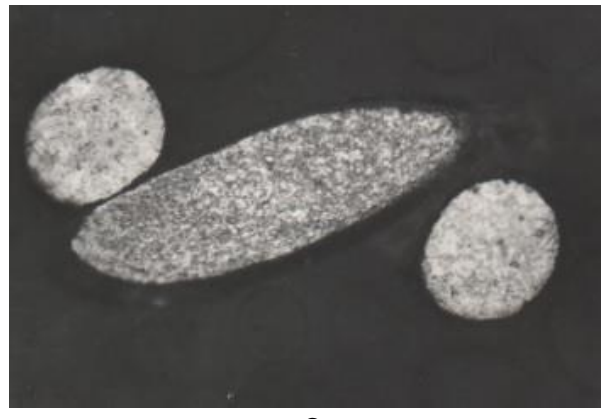

C

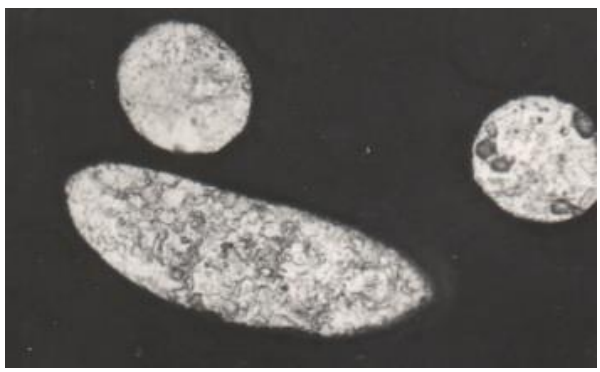

E

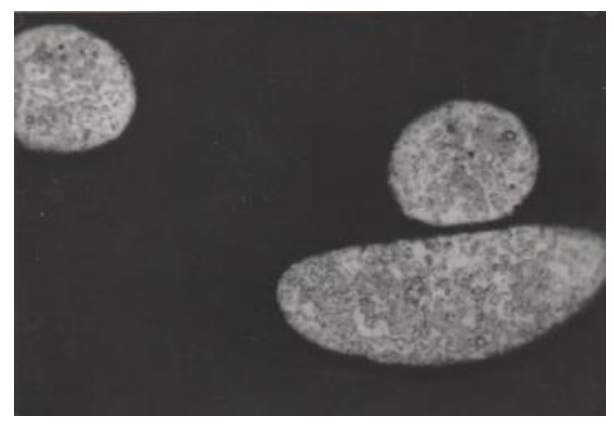

D

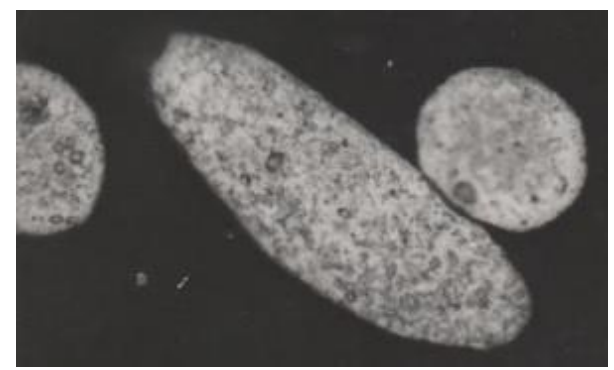

$\mathrm{F}$

Fig. 6. Photographs of non-etched micro-sections and micro-structure of steel: $A$-non-etched micro-section of a mesh from the AT propellant tank; $B$-non-etched microsection of a mesh from the UDMH propellant tank; $C$-microstructure of a mesh from the AT No. 1; D-microstructure of a mash from the UDMH No. 1; E-microstructure of a mesh from the AT No. $1 ; F$-microstructure of a mesh from the UDMH No. 1

\section{Analysis of the research results}

The main factor determining the change in the design parameters of capillary intake devices after a long stay of its structural elements in the liquid propellant components (AT and UDMH) and under their vapors is a change in the characteristics of the capillary holding capacity of the mesh phase separators compared to reference patterns of meshes. formula):

Capillary holding capacity, in turn, depends on the following factors (see

a) physico-chemical properties of the propellant used;

b) propellant temperature;

c) geometric dimensions of the mesh (wire diameter and mesh cell sizes);

d) contact angle of the propellant with the mesh material.

Moreover, the parameters a), b), c) and d) are mutually dependent on each other and have a complex effect on capillary holding capacity.

Based on the obtained experimental data (see Fig. 5 (A, B)), a linear regression of changes in the approximate values of the parameters of capillary 
holding capacity for 31 years of the stay of the elements of capillary intake devices in liquid propellant components (AT and UDMH) and under vapors with superimposed regression of the change in the parameters of capillary holding capacity under the condition of speed corrosion of stainless steel $-1 \cdot 10^{-4} \mathrm{~mm} /$ year was constructed, which is shown in Fig. 7 (A, B).

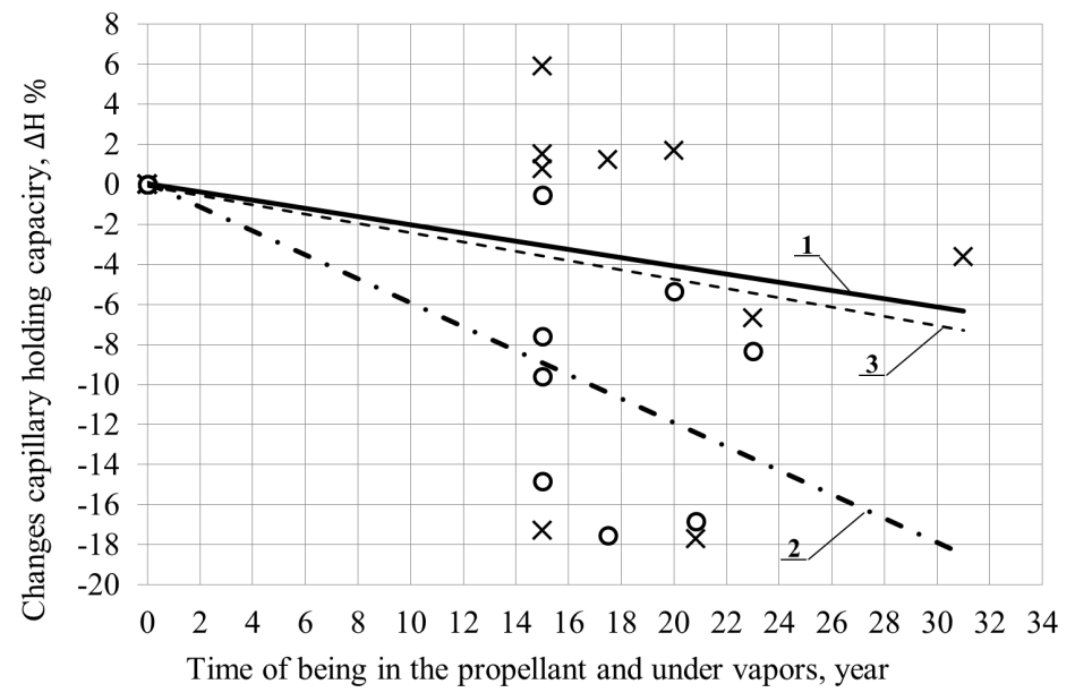

Fig. 7. Linear regression graph of changes in the approximated values of the parameters of capillary holding capacity over the 31 years of the stay of elements of capillary intake devices in liquid propellant components and under its vapors with superimposed regression of changes in the parameters of capillary holding capacity properties under the condition of steel corrosion rate $-1 \cdot 10^{-4} \mathrm{~mm} / \mathrm{year}$

In Fig. 7 shows: 1 - the curve of changes in the parameters of capillary holding capacity for the screen of the mesh phase separator located in the AT, approximated by the results of experimental data; 2 - the curve of changes in the parameters of capillary holding capacity for the screen of the mesh phase separator located in the UDMH, approximated by the results of experimental data; 3 - the curve constructed on the basis of the corrosion rate of stainless steel $1 \cdot 10^{-4} \mathrm{~mm} /$ year; experimental values of arithmetic mean values of capillary holding capacity: $\times-$ AT, o- UDMH.

As can be seen from Fig. 7 for 31 years of being in the propellant components and under their vapors, the average approximated value of the capillary holding capacity for the screen of the mesh phase separator located in the AT has decreased by $\sim 6.3 \%$ with respect to the reference mesh, and for those in UDMH - by $\sim 18.5 \%$.

The results of chemical analysis of samples of propellant components (AT and UDMH) discharged from propellant systems after long-term operation showed 
that they practically did not change their indicators compared to the initial values given in the standards.

Therefore, the influence of changes in the physico-chemical properties of the fuel used on the capillary holding capacity can be neglected.

The effect of temperature was taken into account by using temperatureaveraged values of capillary holding capacity.

Deposits found on meshes from a propellant tank of an oxidizer (AT) during defect detection hydrated nitrates of metal, are mainly aluminum and iron. Also, in the composition of the deposits, there are oxides, metal chlorides and water in small quantities. The formation of deposits occurred during technological operations (draining of propellant components, neutralization, opening of propellant tanks during fault detection) and cannot fully be a consequence of corrosion changes in the microstructure of the structural materials of the mesh phase separator due to its long stay in the AT.

Inspection of the screen of mesh phase separators from UDMH propellant tanks showed that the surface of the samples did not change compared to the initial one, there was neither darkening of the surface, nor the presence of deposits, or deposits.

Metallographic studies of samples of reticulated mesh phase separator that have been in the AT for a long time and in UDMH showed that the structural material of the presented samples of mesh of local corrosion lesions (intergranular, pitting, contact, crevice corrosion, cracks) was not detected.

Thus, one of the main factors affecting the change in the parameters of capillary holding capacity can be considered the change in the geometric dimensions of the mesh (excluding mechanical damage to the main structural material of the mesh), due to uniform corrosion.

Available domestic and foreign data on the rate of uniform corrosion for stainless steel indicate [16-18]:

- corrosion rate in AT at $50{ }^{\circ} \mathrm{C} \leq 1 \cdot 10^{-4} \mathrm{~mm} /$ year;

- corrosion rate in UDMH at $50{ }^{\circ} \mathrm{C} \leq 1 \cdot 10^{-4} \mathrm{~mm} /$ year.

It should be noted that for AT, the given values of the corrosion rate are an upper estimate, since they do not take into account the influence of super-blow gases and storage temperature regimes of charged and amplified upper stages of spacecraft.

So, nitrogen, which is the boost gas in this case, reduces the corrosion rate by 8 times in comparison with atmospheric air. And the corrosion of steel stored in non-leaking AT residues if nitrogen is used as boost gas is 10 times lower than when the air is used.

For the screen of mesh phase separators located in the AT and UDMH, the capillary holding capacity parameters decreased by $\sim 7.2 \%$ over a period of 31 years, which would correspond to a decrease in the nominal wire diameter (55 microns) at 6.2 microns. This indicator is close to the values of the minimum diameters of wire meshes measured by the optical method (see Fig. 5 (A, B)). 
For the screen of mesh phase separators located in the AT, the change in the parameters of capillary holding capacity over a period of 31 years does not contradict theoretical calculations about the corrosion rate of stainless steel in the liquid phase of AT and under its vapors. Over the course of 31 years, due to a corrosive change in the geometric dimensions of the mesh cells, the capillary holding capacity of the mesh phase separators has decreased by $\sim 7.2 \%$, while according to experimental data, the capillary holding capacity has decreased by $\sim 6.3 \%$.

For the screen of mesh phase separators found in UDMH, the change in the parameters of capillary holding capacity over a period of 31 years significantly exceeds the possible change in the value of capillary holding capacity due to corrosion $\sim 18.5 \%$ against $\sim 7.2 \%$.

This may indicate that the main change in the parameters of capillary holding capacity occurs due to a change in the contact angle $(\theta)$.

Based on the assumption that the value of the contact angle $(\theta)$ is not equal to zero, using formula and the experimentally obtained value of the change in capillary holding capacity which is equal $\sim 18.5 \%$ of the value for the reference mesh, we define the arithmetic mean value of $\theta$ in the 31 year, and it will be $\sim 28.6^{\circ}$ $[1,12,13,19,20]$.

The reasons for the proposed change in the contact angle require additional study and analysis, as well as the reasons for the capillary holding capacity to exceed the upper tolerance limit calculated in accordance with the data on the allowable deviations of the geometric parameters of mesh No. 008 in accordance with the technical conditions (see Fig. 4 (A), curve 1), both for mesh phase separators that have been in the liquid phase of AT and under vapors for a long time, and for reference meshes, since it cannot be fully explained by grid cells impurity. An increase in the parameters of capillary holding capacity is not unambiguously a positive factor and should be considered within the framework of the operation of the entire pneumohydraulic system of the stage, since it can lead to an increase in the resistance of the mesh phase separator.

\section{Conclusions}

The results of a long-term study of the effect of a long stay (more than 30 years) of elements of capillary intake devices - mesh phase separators in the components (and under their vapor) of liquid propellant components (AT and UDMH) on the change in their operating parameters (characteristics), detail that:

- for the 31-year stay in the liquid propellant components and under its vapors, the average approximated value of the main parameter that determines the operability of capillary intake devices - the capillary holding capacity of the mesh phase separators for the mesh located in the AT decreased by $\sim 6.3 \%$, with respect to the reference mesh, and for those in UDMH - by $\sim 18.5 \%$; 
- the most likely reason for the decrease in capillary holding capacity for the mesh phase separators located in the AT is the uniform corrosion of the structural materials of the mesh because its value is close to theoretical, which is $\sim 7.2 \%$ for 31 years;

- for the mesh phase separators found in UDMH, the decrease in capillary holding capacity over a period of 31 years is significantly higher than expected as a result of uniform corrosion $(\sim 18.5 \%$, against $\sim 7.2 \%)$, which may be due to an increase in the arithmetic mean of the contact angle $(\theta)$ from zero to a value of $\sim 28.6^{\circ}$. The reasons for the change in the contact angle require further study and analysis.

Based on the fact that when designing a continuity system, the parameters of the mesh phase separators are determined with a safety factor of 2, the results of studies of samples of the mesh phase separator indicate that during their long stay in liquid propellant components (AT and UDMH ) and under their vapors for 31 years, a decrease in the parameters of capillary holding capacity by $\sim 6.3 \%$ (for AT) and by $\sim 18.5 \%$ (for UDMH) does not violate the design parameters of the mesh phase separators of capillary filters molecular devices.

The research results indicate that steel mesh No. 008 used as mesh phase separators fully meets the requirements for liquid storage and selection systems and for capillary intake devices, as their integral part at the present stage of development space exploration programs, namely:

- reusable features;

- long period of operation;

- operability in aggressive environments.

The use of steel mesh No. 008 in the functional elements of spacecraft flight continuity systems (using AT and UDMH as propellant) and space station propellant storage systems will definitely not lead to a critical decrease in their design parameters over a period of 31 years operation.

\section{References}

1. Bagrov, V. V., Kurpatenok, A. V., and Poljaev V. M. Capillary systems for selecting liquid from spacecraft tanks, UNPC «JeNERGOMASh» Publ., 1997, 328. (in Russian)

2. Siedykh, I. V. and Smolenskij, D. Je., Experimental confirmation of the operability of a capillary intake device in the separation of the spacecraft. Mechanics gyroscopic systems, 2017, 33, 105-14. DOI:10.20535/0203-3771332017119618. (in Russian)

3. Siedykh, I. V., Smolenskij, D. Je., Nazarenko, D. S., Experimental confirmation of the operability of a capillary intake device (mesh separator) during a program turn, Visn. Dnipr. un-tu. Raketno-kosmichna tehnika. 2018, 21, 26, 112-19. (in Russian)

4. Snead, J. M., Hellman, B. H., Near-future reusable space logistics vehicles, In: $43^{\text {rd }}$ Propulsion Conference \& Exhibit, 2007 AIAA/ASME/SAE/ASEE, 2007, 1-20. DOI:10.2514/6.2007-5847. 
5. Bienhoff, D., The future of commercial space transportation, 2019, https://www.thespacereview.com/article/3776/1.

6. Kornuta, D., Abbud-Madrid A., Atkinson J., et al. Commercial lunar propellant architectechnical specificationre. A collaborative stechnical specificationdy of lunar propellant production, 2019, 188. DOI:10.1016/j.reach.2019.100026.

7. Abrego, A., Bair, C., Hink, A., et al. Project Hyreus. Mars sample retechnical specificationrn mission utilizing in sitechnical specification propellant production Washington Univ.; Dept. of Aeronautics and Astronautics, NASA-CR-197189, 1993, 383.

8. Walter, T., Philipp, B., Jaekle, D., and Netter, G. The Evolutionary forces and the design and development of propellant management devices for space flight in europe and the united states, In conference: Space Propulsion, 2016, 25.

9. Walter, T. and Jaekle, D., Review and history of ATK space systems surface tension PMD tanks, In conference: Space Propulsion, 2018, 24.

10. Hartwig, J. W., A detailed historical review of propellant management devices for low gravity propellant acquisition, Cleveland, GRC-E-DAA-TN32675, 2016, 25.

11. Woven with square micron mesh. Technical specification., OJSC LEPSE, 1999, 2. (in Russian)

12. Shevchenko, B. A. Estimated and experimental method for the development of means for collecting fuel components from tanks of aircraft with a liquid rocket engine, Dnepropetrovsk, KB «Juzhnoe» Publ., 1990, 209. (in Russian)

13. Chelomey, V. N. et al. Pneumohydraulic systems of propulsion system with liquid rocket engines, Moscow, Mashinostroenie Publ., 1978, 240. (in Russian)

14. Hartwig, J. W. Liquid acquisition devices for advanced in space cryogenic propulsion systems, Elsevier Inc., 2015, 488.

15. Fouad, A. On the pressure drop of fluids through woven screenmeshes, Chemical engineering science, 2019, 207, 464-78. DOI:10.1016/j.ces.2019.06.046

16. Uney, P. E. and Fester, D. A. Material compatibility with space storable propellants, California, Prepared for Jet Propulsion Laboratory California Institechnical specificationte of Technology, 1972.

17. Torrance, P. R., Lyndon, B. Point model for the formation of metal nitrate in nitrogen tetroxide oxidizer, Houston, NASA-TP-3107, 1991.

18. Michael, F.A., Norman, L., Simon, A., Dove, Wood. Corrosion of T1-6A1-4V alloy and 304L stainless steel in liquid nitrogen oxides, Journal of Propulsion and Power, 1996, 12, 1. DOI: $10.2514 / 3.23989$.

19. Fester, D. A., Villars, A. S., Uney, P.E., Surface tension propellant acquisition system technology for Space Shattle reaction control tank, In: $11^{\text {th }}$ AIAA and SAE Propulsion conference, 1974, 8.

20. Hartwig, J. W. and Kamotani, Ya., The static bubble point pressure model for cryogenic screen channel liquid acquisition devices, International Journal of Heat and Mass Transfer, 2016, 101, 502-16. DOI:10.1016/j.ijheatmasstransfer.2016.05.024 


\title{
ИССЛЕДОВАНИЕ ВЛИЯНИЯ ДЛИТЕЛЬНОГО ПРЕБЫВАНИЯ ЕЛЕМЕНТОВ КАПИЛЯРНЫХ ЗАБОРНЫХ УСТРОЙСТВ В КОМПОНЕНТАХ ЖИДКИХ РАКЕТНЫХ ТОПЛИВ НА ИХ ПАРАМЕТРЫ
}

\author{
А. Н. Минай, О. М. Иванов, И. В. Седых
}

В настоящей работе рассмотрены результаты многолетнего исследования влияния длительного пребывания (более 30 лет) элементов капиллярных заборных устройств - капиллярных фазоразделителей в компонентах (и под парами) жидкого ракетного топлива $\left(\mathrm{N}_{2} \mathrm{O}_{4}\right.$ и $\left.\left(\mathrm{CH}_{3}\right)_{2} \mathrm{~N}_{2} \mathrm{H}_{2}\right)$ ) на изменение их рабочих параметров (характеристик). В процессе исследований проведены работы по извлечению капиллярных фазоразделителей из топливных баков дефектируемых ступеней ракет после их нейтрализации, анализу химического состава веществ. находящихся на сетках капиллярных фазоразделителей, определению капиллярной удерживающей способности сеток, замеру геометрических размеров сеток оптическим методом и проведению металлографических исследований образцов сеток.

В результате проведенных работ авторами определена величина снижения капиллярной удерживающей способности сеток капиллярных фазоразделителей за 31 год их пребывания в компонентах жидкого ракетного топлива и под их парами, проведен анализ основных факторов, повлиявших на изменение проектных параметров капиллярного заборного устройства: равномерных коррозионных поражений и локальных изменений микроструктуры конструкционного материала сеток, а так же изменению значения краевого угла контакта топлива с материалом сеток. 